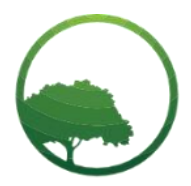

Research in Business \& Social Science

IJRBS VOL 11 NO 1 (2022) ISSN: 2147-4478

\title{
Promoting online purchase intention through website quality, EWOM, receiver perspective, consumer satisfaction and brand image
}

\author{
(D) Aditya Indra Wicaksono ${ }^{(a) *(1)}$ Asmai Ishak ${ }^{(b)}$ \\ (a) Magister Management Program, Faculty of Business and Economics, Universitas Islam Indonesia, Indonesia \\ (b) Senior Lecturer in Marketing, Faculty of Business and Economics, Universitas Islam Indonesia, Indonesia
}

\begin{tabular}{l} 
A R T I C L E I N F O \\
\hline Article history: \\
Received 16 December 2021 \\
Received in rev. form 02 Feb. 2022 \\
Accepted 06 February 2022 \\
Keywords: \\
Website quality, EWOM, receiver \\
perspective, consumer satisfaction, \\
brand image, online purchase \\
intention \\
JEL Classification: \\
L1, M21, M31
\end{tabular}

\begin{abstract}
A B S T R A C T
Technological developments and pandemic conditions that limit people's movement have triggered an increase in the use of online shopping platforms. Therefore, it is necessary to analyze in more depth the factors that increase online purchase intention. This study aims to analyze the effect of website quality on EWOM and the effect of EWOM and receiver perspective on consumer satisfaction and brand image. An analysis was also conducted on the influence of satisfaction and brand image on online purchase intention. This research is a quantitative study using primary data from distributing questionnaires to 250 online shopping platform consumers. The data in this study were then analyzed using the SEM (Structural Equation Model) method with AMOS 24 software. The results of this study indicate that website quality has a significant effect on EWOM. Furthermore, the receiver perspective and EWOM have a significant effect on consumer satisfaction and brand image. Consumer satisfaction and brand image have a significant effect on online purchase intention.
\end{abstract}

(C) 2022 by the authors. Licensee SSBFNET, Istanbul, Turkey. This article is an open access article distributed under the terms and conditions of the Creative Commons Attribution (CC BY) license (http://creativecommons.org/licenses/by/4.0/).

\section{Introduction}

Marketing has always been recognized as one of the main keys to the success of a business. Because it is recognized and realized by business people, the competition in marketing is certainly getting tougher. Especially in this digital era, distance is no longer a limitation in selling products, so many consumers are now turning to online shopping. Discussions related to marketing strategies are always associated with digital technology. Digital technology, especially social media, is able to facilitate the marketing of products or services to gain consumer purchase intention without being limited by distance and time. Online purchase intention is a combination of consumer interest in a brand or product sold online and the likelihood of buying the item. This is closely related to attitudes and preferences towards a particular brand or product. So, it can be understood that purchase intention is one indicator of the good perception of consumers towards a product or service (Tandon et al. 2020).

There are many digital platform users and they have increased in 2020. This increase was also due to the Covid-19 pandemic, which limits people's movement so that buying and selling online is one of the most popular alternatives. This shows that digital platforms have great opportunities in developing businesses and doing online marketing. In the midst of increasing users of online shopping platforms, there are companies that are able to gain market share on a large scale, but there are also companies that are stagnant and lose in market competition. it is necessary to further analyze what factors are able to increase consumer interest in shopping online.

So that a term has emerged that has been discussed by several researchers recently related to marketing in the online world that is able to introduce a product or service brand and bring in many customers from various locations massively, namely Electronic Word

\footnotetext{
* Corresponding author. ORCID ID: 0000-0002-8013-8995

(C) 2022 by the authors. Hosting by SSBFNET. Peer review under responsibility of Center for Strategic Studies in Business and Finance.

https://doi.org/10.20525/ijrbs.v11i1.1554
}

Citation: Wicaksono, A. I., \& Ishak, A. (2022). Promoting online purchase intention through website quality, EWOM, receiver perspective, consumer satisfaction and brand image. International Journal of Research in Business and Social Science (2147- 4478), 11(1). 
of Mouth (hereinafter abbreviated as E-WOM) (Aslam et al., 2019; Septiari, 2018; Setyaning \& Nugroho, 2020; Yang et al., 2015; Bilal et al., 2020). E-WOM has an important role in online marketing because consumer ratings of a product refer to the product's EWOM (Setyaning \& Nugroho, 2020; Yang et al., 2015).

Apart from product quality, good E-WOM is also related to website quality. Several previous studies have found that E-WOM can be improved through website quality (Aslam et al., 2019; Septiari, 2018; Setyaning \& Nugroho, 2020; Yang et al., 2015; Bilal et al., 2020). Website quality is the main source for consumers to give an assessment of a digital platform. Consumers will assess and gain experience regarding the ease of use of a website, how informative a website is and whether or not the website design is attractive so that it leads to conclusions for these consumers regarding the quality of the digital platform. This conclusion becomes a reference and material for consumers in conducting E-WOM, so that the quality of the website certainly has an influence in creating E-WOM (Septiari, 2018; Setyaning \& Nugroho, 2020).

E-WOM has a significant positive role for companies and e-commerce platforms. With positive E-WOM spread in cyberspace, consumers will be more confident in the products being sold and able to increase consumer satisfaction. Several previous studies have also proven through empirical studies that E-WOM is able to increase consumer satisfaction (Setiawan et al., 2014; Tandon et al., 2020; Kuo \& Nakhata, 2019; Aakash \& Gupta, 2020; Aslam et al., 2019).

In addition to increasing consumer satisfaction, E-WOM has also been shown to be able to improve the company's brand image (Kala \& Chaubey, 2018; Tariq et al., 2017; Farzin \& Fattahi, 2018; Al Halbusi \& Tehseen, 2018; Aslam et al., 2019) although there is a study which states that in certain cases, E-WOM is not able to have a significant influence on the brand of a product as research by Syahdiany \& Trinanda (2019) who conducted an analysis on Transmart consumers in Padang and Pasaribu \& Sugiarto which conducted an analysis on Oppo smartphone consumers. in Medan. However, the majority of previous researchers found that E-WOM was able to have a significant effect on the company's brand. The spread of E-WOM is able to shape the company's brand and ultimately improve the company's brand image. Brand image is very important for the company because it is a picture of the public's mindset towards the company. Brand image leads to public opinion regarding a product or platform that with that opinion can attract consumers (Kala \& Chaubey, 2018; Tariq et al., 2017).

The role of E-WOM in increasing consumer satisfaction and brand image has a significant positive impact on the company. This is because with the achievement of consumer satisfaction and a good brand image, the company will be able to attract more consumers. Several previous studies also provide empirical evidence that consumer satisfaction can affect people's purchase intention (Tandon et al., 2020; Cuong, 2020; Dash et al., 2021; Khatoon et al., 2020; Dhingra et al., 2020) although there are contradictory findings by Permana et al. (2020) who found that satisfaction had no significant effect on purchase intention.

Consumer satisfaction is very important for companies including e-commerce platforms. With customer satisfaction, consumers have a desire to buy back the products offered. Consumer satisfaction starts from the perspective of the consumer regarding a product. If the perspective of the consumer is good, it will foster satisfaction for consumers (Moore $\&$ Lafreniere, 2020). The receiver perspective is proven to have an influence in creating customer satisfaction (Moore \& Lafreniere, 2020; Heo, 2020; Aslam et al., 2019) and brand image (Le et al., 2018; Kursan et al., 2020; Aslam et al., 2019).

Empirical studies from several previous studies also prove that increasing people's purchase intention can be pursued through increasing brand image (Hien et al., 2020; Kala \& Chaubey, 2018; Tariq et al., 2017; Farzin \& Fattahi, 2018; Al Halbusi \& Tehseen, 2018). The emergence of a good brand image of a particular company or product starts from the good perspective of consumers towards the company or product (Le et al., 2018; Kursan et al., 2020; Aslam et al., 2019).

From previous presentations and findings, it is evident that the quality of the website, E-WOM, consumer satisfaction, brand image, recipient perspective and people's purchase intention are very important for companies, especially e-commerce platforms. Several studies also still give contradictory results regarding the relationship between E-WOM and brand image and satisfaction with purchase intention so that this study will analyze further on Shopee e-commerce consumers. E-WOM is a topic that has been widely discussed in the previous literature but there is still little that is related to the quality of the website and the perspective of the recipient (Aslam et al. 2019). Therefore, this study provides novelty in the analysis of the relationship between website quality and recipient perspective on E-WOM, consumer satisfaction and brand image on the shopee e-commerce platform. Another novelty provided in this study is related to the condition of respondents in doing online shopping during the Covid-19 pandemic.

\section{Literature Review}

\section{Empirical Review and Hypothesis Development}

\section{Website Quality and E-WOM}

Website is an online media that contains information in the form of animation, still images, sound, writing that are interconnected statically and dynamically to form a network (Yang et al. 2015). The quality of the website is the result of user evaluation of a website including ease of use, usefulness, level of attractiveness and easy access (Aslam et al. 2020). Therefore, creating a quality website is one surefire way to shape consumer perceptions of the company so that one of the positive impacts is being able to increase E-WOM positively (Aslam et al., 2019; Septiari, 2018; Setyaning \& Nugroho, 2020; Yang et al., 2015; Bilal et al., 2020). There are certain 
attributes that affect consumers' minds when they do online shopping and that attribute is the quality of the website. The influence of website quality on E-WOM does not only occur and is intended for consumers in Indonesia but also applies to consumers outside Indonesia as researched by Yang et al. (2015) who analyzed the quality of the website from the aspect of website attributes and found that website attributes consisting of visual aesthetics, navigation, user friendliness, privacy/security, entertainment, and community driveness affect participation, eWOM and Co-Shopping among students in America. As for Bale et al. (2020) found the same in 756 consumers in China. Therefore, the following hypothesis is formulated:

\section{H1: Website quality has a positive effect on E-WOM:}

\section{E-WOM and Consumer Satisfaction}

Word of mouth is a marketing process orally, in writing, or through electronic communication tools with other intermediaries because it relates to the post-purchase experience. Word of Mouth has great power to impact on the buying behavior of customers or consumers (Tandon et al. 2020). Electronic word of mouth is the implementation of word of mouth in cyberspace or the digital world (Aslam et al. 2019). E-WOM is a one-way or two-way communication that is carried out online without meeting face to face. EWOM contains positive or negative expressions which are a form of marketing communication to potential or former customers. customers/consumers through social media. With E-WOM, the marketing process can be carried out more easily because it can shorten time and eliminate distance constraints (Kuo \& Nakhata, 2019). Several previous studies found that E-WOM was able to have a significant effect on consumer satisfaction (Setiawan et al., 2014; Tandon et al., 2020; Kuo \& Nakhata, 2019; Aakash \& Gupta, 2020; Aslam et al., 2019) and brands. image (Kala \& Chaubey, 2018; Tariq et al., 2017; Farzin \& Fattahi, 2018; Al Halbusi $\&$ Tehseen, 2018; Aslam et al., 2019). Therefore, E-WOM has an important role in marketing a product or is an effort to improve the brand. Although there are studies that state that in certain cases, E-WOM is not able to have a significant influence on the brand of a product as research by Syahdiany \& Trinanda (2019) who conducted an analysis on Transmart consumers in Padang and Pasaribu \& Sugiarto which conducted an analysis on smartphone consumers. Oppo in Medan. However, the majority of previous researchers found that E-WOM was able to have a significant effect on the company's brand. So the hypothesis is formulated as follows:

H2: E-WOM has a positive effect on consumer satisfaction

\section{E-WOM and Brand Image}

In addition to having an influence on consumer satisfaction, E-WOM is also proven to have an effect on brand image. Kala \& Chaubey, (2018) analyzed the role of E-WOM on 313 online consumers in India and found that E-WOM has an effect on brand image and purchase intention. The brand image is also able to moderate the relationship between E-WOM and purchase intention. Likewise with Tariq et al., (2017) who conducted an analysis of 300 consumers in Rawalpindi and Islamabad and found that E-WOM and brand awareness together can influence brand image. Farzin \& Fattahi, (2018) state the importance of constructs of consumer trust, informational influence, sense of belonging, altruism, moral obligation, and knowledge self-efficacy for consumer engagement in eWOM. Further results in his analysis show that E-WOM, in turn, plays an important role in shaping the brand image in the minds of consumers. As for Al Halbusi \& Tehseen, (2018) analyzed the automobile industry consumers in Malaysia and found that E-WOM has an effect on brand image and purchase intention. Brand image mediates the relationship between E-WOM and purchase intention. Therefore, the following hypothesis is formulated:

H3: E-WOM has a positive effect on brand image

Receiver Perspective and Consumer Satisfaction

The receiver perspective is a response from recipients of information related to a product or service about the information received (Aslam et al. 2019). Due to technological improvements, consumers are more attracted to e-commerce, which gives E-WOM a competitive advantage. The sender is the person who shares the information and the receiver is the person who receives the information. Consumer attitudes and behavior can be influenced by the recipient's perception of the brand. No one can judge how consumers will react and about their attitudes and behavior towards a particular product. It is important to know about the reaction of the recipient. It is important to communicate the right information about the product, so that the recipient perceives things positively. The delivery of the message also has a major impact on the perception of the recipient (Aslam et al. 2019). The receiver perspective is proven to have an influence in creating customer satisfaction (Moore \& Lafreniere, 2020; Heo, 2020; Aslam et al., 2019) This shows that if the receiver perspective is good, customer satisfaction will increase. Conversely, if the receiver perspective is bad, customer satisfaction will decrease. Therefore, the company must be able to control the perspective of the recipient so that it always provides a good perspective for the company. Based on the results of the discussion, the research hypothesis is put forward as follows:

\section{H4: Receiver perspective has a positive effect on consumer satisfaction}

\section{Receiver perspective and Brand Image}

The receiver perspective has several measurements, namely the perspective of previous comments related to a product or platform, the perspective of positive and negative responses related to a product or platform and the perspective of an opinion that spreads on social media related to a particular product or platform (Aslam et al. 2019). The receiver perspective has an important role in 
marketing a product or service. Even more so if the marketing is done online. Several previous studies have empirically proven the important role of the receiver's perspective, such as Moore \& Lafreniere, (2020) finding that WOM (Word of Mouth) affects the receiver's perspective and the receiver's perspective affects the review, helpfulness, satisfaction of consumers. The receiver perspective has been shown to have an influence in creating brand image (Le et al., 2018; Kursan et al., 2020; Aslam et al., 2019). Likewise, with Le et al., (2018) who analyzed 509 consumers and found that the receiver perspective described by the quality of consumer messages related to a product or service can affect the impact of E-WOM in product marketing. The impact of E-WOM in question is consumer satisfaction and brand image. Based on the results of the discussion, the research hypothesis is put forward as follows:

H5: Receiver perspective has a positive effect on Brand Image

\section{Consumer Satisfaction and Purchase Intention}

Consumer satisfaction is a consumer's assessment of the characteristics of a product or service and produces positive results that come from consumption. Ensuring customer satisfaction can be viewed as a company's ability to meet customer expectations, with a high level of satisfaction being a source of a company's competitive advantage (Cuong, 2020). Every company wants its customers to feel satisfied with both the products and services offered. This is because with consumer satisfaction, people's purchase intention is increasing (Tandon et al., 2020; Cuong, 2020; Dash et al., 2021; Khatoon et al., 2020; Dhingra et al., 2020). Although there are contradictory findings by Hutchinson (2009; Permana et al. 2020) who found that satisfaction had no significant effect on purchase intention. Khatoon et al., (2020) conducted an analysis on 235 bank employees and customers in Qatar and found that (E)-banking service quality and satisfaction had a significant effect on purchase intention. Furthermore, satisfaction mediates the relationship between E-banking service quality and consumer purchase intention. Likewise, with Dhingra et al., (2020) who conducted an analysis of 278 popular website users and found that online service quality and consumer satisfaction had a significant effect on consumer purchase intention. Based on the results of the discussion, the research hypothesis is put forward as follows:

H6: Consumer satisfaction has a positive effect on purchase intention

\section{Brand Image and Purchase Intention}

Brand image is basically a product's reputation and perception created in the minds of customers. Good customer relationships are built on the basis of a positive brand image because for customers commitment is a key factor for a promising brand. The negative brand image of a brand will create a result of neglect (Hien et al. 2020). Brand image consists of two factors, namely brand knowledge and customer response. Consumers, first seek knowledge related to the brand and then knowledge. Consumers around the world are modernized and interdependent on technology. Online advertising plays a major role and has become common among people (Al Halbusi \& Tehseen, 2018). Several previous studies have analyzed and proven the important role of brand image for a company in its marketing concept. Hien et al., (2020) analyzed 283 consumers of household electrical appliances in Ho Chi Minh and Da Nang cities and found that country of origin had an effect on brand image and brand evaluation. Furthermore, brand image and brand evaluation have an effect on purchase intention. The influence of brand image on purchase intention is also empirically proven by Farzin \& Fattahi, (2018) on students at Azad Islamic University and Al Halbusi \& Tehseen, (2018) on automobile industry consumers in Malaysia..Based on the results of the discussion, the research hypothesis is put forward as follows:

H7: Brand image has a positive effect on purchase intention

\section{Research Framework}

Based on theoretical studies and previous research, the relationship between the variables of website quality, E-WOM, recipient perspective, consumer satisfaction, brand image and purchase intention can be formulated within the framework of the research concept as shown in Figure 2.1

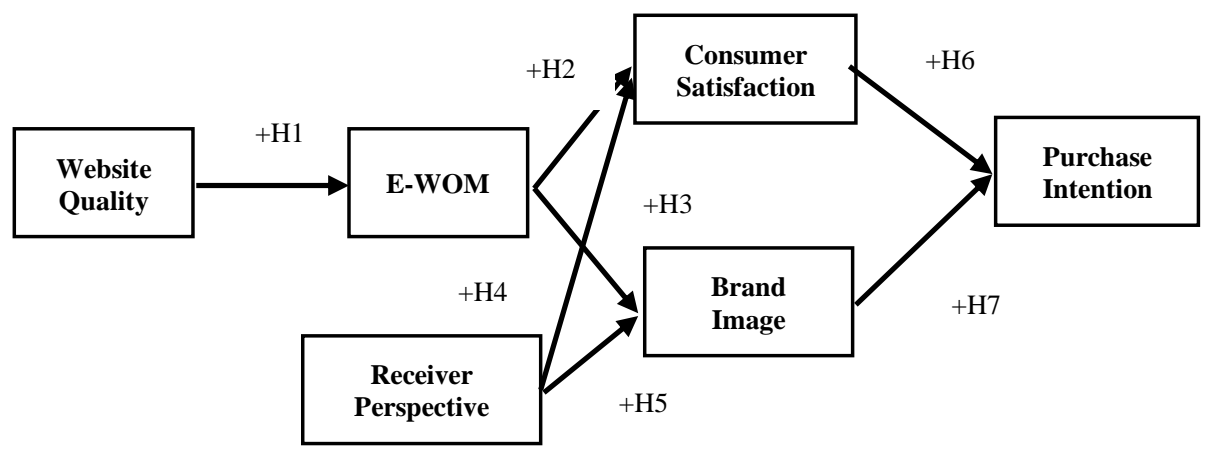

Figure 1: Research Framework 


\section{Research and Methodology}

The population used in this study is e-commerce consumers. E-Commerce is a new trend and is in great demand by the public as a new lifestyle. Supported by restrictions on social activities due to the Covid-19 pandemic which resulted in a large increase in purchasing goods online, e-commerce consumers are interesting to analyze (Kominfo, 2020).

In determining the number of samples, the formula that can be used is referring to Roscoe (1975) which states that the number of samples will be determined based on the results of the calculation of the minimum sample. The determination of the minimum number of samples for SEM according to Roscoe (1975) is the number of indicators x (10 to 20 times). Based on these guidelines, the minimum sample size for this study is the minimum sample $=23 \times 10=230$ respondents. Based on the formula above, the minimum number of samples in this study is 230 respondents. This study will use a sample of 250 respondents and this number is above the minimum required number of respondents.

This study uses 6 variables consisting of 2 exogenous variables, namely website quality and recipient perspective and 4 endogenous variables which include E-WOM, consumer satisfaction, brand image and purchase intention. The definitions and proxies of each variable are as follows:

i. Website quality is the result of user evaluation of a website including ease of use, usefulness, level of attractiveness and easy access (Aslam et al. 2020). The measurements are as follows (Aslam et al. 2020):
a. Attractive appearance.
b. Complete information.
c. Reviews from buyers

ii. E-WOM is a communication of two parties or one party only in social media about the evaluation of a product (Aslam et al. 2020). The measurements are as follows (Aslam et al. 2020):
a. Positive opinion regarding the brand
b. Convincing information
c. Objective comments / Reviews
d. Trusted source

iii. The receiver perspective is a response from the recipient of information related to a product or service regarding the information received (Aslam et al. 2019). The measurements are as follows (Aslam et al. 2020):
a. Comments for consideration
b. Comments make an impact
c. Comments form opinions

iv. Consumer satisfaction is a consumer's assessment of the characteristics of a product or service and produces positive results that come from consumption (Cuong, 2020). The measurements are as follows (Aslam et al. 2020):
a. Post-purchase pleasure.
b. Enjoyable experience
c. Trust.
d. Recommendations

v. Brand image is basically a product's reputation and perceptions created in the minds of customers (Hien et al. 2020). The measurements are as follows (Aslam et al. 2020):
a. Different image with competitors.
b. Clean image.
c. Strong position in the market.
d. Brand competitiveness.

vi. Consumer interest is the stage where consumers choose from a number of brands that are included in a series of choices, and finally buy by choosing an alternative or process that consumers prefer to buy the product or service. various considerations (Tariq et al. 2017). The measurements are as follows (Aslam et al. 2020):
a. Interest
b. Curiosity
c. Purchase
d. Repurchase
e. Recommendations 


\section{Findings and Discussion}

The analysis used to prove the hypothesis is the calculation of the Structural Equation Model (SEM) with AMOS 24 software. The model development in this research is based on the concept of data analysis. In general, this research model consists of 2 exogenous variables and 5 endogenous variables. The exogenous variables in this study are website quality (KW) and recipient perspective (PP). The endogenous variables in this study are EWOM (electronic word of mouth), consumer satisfaction (KK), brand image (BI) and purchase intention (MB).

\section{Respondents Characteristics}

The characteristics of the respondents in this study were divided into several aspects including the gender of the respondent, the age of the respondent, the respondent's occupation, whether or not the user of the online trading platform was used, the intensity of the use of the online trading platform and the duration of the use of the online trading platform. From the aspect of gender, it is known that the female respondents in this study amounted to 89 respondents or $35.6 \%$ while the male respondents were 161 or $64.4 \%$ of the total 250 respondents, so that there were more male respondents than female. Furthermore, from the aspect of age, the majority of respondents in this study were aged 26-35 years with a total of 208 respondents or $83.2 \%$ of the total respondents.

Based on occupation, it is known that most of the respondents in this study have jobs as private employees with a percentage of $50.4 \%$. Furthermore, it is known that the respondents in the study are all users of the online buying and selling platform and there are no respondents who do not use the online trading platform. From the aspect of intensity in using online shopping platforms, it is known that the respondents in this study have the most frequent intensity in using online shopping platforms, as many as 122 respondents or $48.8 \%$. Meanwhile, based on the period of use of the online shopping platform, the respondents in this study at most had a period of using the online shopping platform for $2.01-3$ years, as many as 70 respondents or $28 \%$.

\section{Confirmatory Analysis}

Confirmatory analysis is used to test the concept that is built using several measurable indicators. In the confirmatory analysis, the first thing to look at is the loading factor value of each indicator. Loading factor can be used to measure construct validity where a questionnaire is said to be valid if the questionnaire is able to reveal something that is measured by the questionnaire. According to Hair et al. (2010) the minimum number of factor loading is 0.5 or ideally 0.7 . If there is a value that is still below 0.5 , it will be removed from the analysis.

Furthermore, the reliability test was carried out. The reliability coefficient ranges from $0-1$, so the higher the coefficient (close to the number 1), the more reliable the measuring instrument is. Construct reliability is good if the construct reliability value is $>0.7$ and the variance extracted value is $>0.5$ (Yamin \& Kurniawan, 2009). The results of the validity and reliability tests are shown in the table1.

Table 1: Validity and Reliability Test

\begin{tabular}{|c|c|c|c|c|c|}
\hline Indicator & $\begin{array}{l}\text { Standard } \\
\text { Loading }\end{array}$ & Standard Loading & Measurement Error & $\mathbf{C R}$ & VE \\
\hline KW3 & 0,824 & 0,679 & 0,321 & \multirow[t]{3}{*}{0,8} & \multirow[t]{3}{*}{0,6} \\
\hline KW2 & 0,78 & 0,608 & 0,392 & & \\
\hline KW1 & 0,794 & 0,630 & 0,370 & & \\
\hline EW1 & 0,79 & 0,624 & 0,376 & \multirow[t]{4}{*}{0,8} & \multirow[t]{4}{*}{0,5} \\
\hline EW2 & 0,705 & 0,497 & 0,503 & & \\
\hline EW3 & 0,738 & 0,545 & 0,455 & & \\
\hline EW4 & 0,726 & 0,527 & 0,473 & & \\
\hline PP3 & 0,796 & 0,634 & 0,366 & \multirow[t]{3}{*}{0,8} & \multirow[t]{3}{*}{0,6} \\
\hline PP2 & 0,782 & 0,612 & 0,388 & & \\
\hline PP1 & 0,803 & 0,645 & 0,355 & & \\
\hline KK1 & 0,783 & 0,613 & 0,387 & \multirow[t]{4}{*}{0,9} & \multirow[t]{4}{*}{0,6} \\
\hline KK2 & 0,803 & 0,645 & 0,355 & & \\
\hline KK3 & 0,806 & 0,650 & 0,350 & & \\
\hline KK4 & 0,681 & 0,464 & 0,536 & & \\
\hline BI1 & 0,652 & 0,425 & 0,575 & \multirow[t]{4}{*}{0,8} & \multirow[t]{4}{*}{0,6} \\
\hline $\mathrm{BI} 3$ & 0,844 & 0,712 & 0,288 & & \\
\hline $\mathrm{BI} 2$ & 0,85 & 0,723 & 0,278 & & \\
\hline BI4 & 0,632 & 0,399 & 0,601 & & \\
\hline MB1 & 0,745 & 0,555 & 0,445 & \multirow[t]{4}{*}{0,9} & \multirow[t]{4}{*}{0,6} \\
\hline MB2 & 0,682 & 0,465 & 0,535 & & \\
\hline MB4 & 0,809 & 0,654 & 0,346 & & \\
\hline MB3 & 0,836 & 0,699 & 0,301 & & \\
\hline
\end{tabular}


From Table 1 it can be seen that all indicators in this study already have a loading factor value of more than 0.5. Construct reliability (construct reliability) all variables have shown 0.7. As for the variance extracted in this study, each variable also has a value of 0.5 . So it can be concluded that the questionnaire used for this research is valid and reliable.

Furthermore, the conformity test of the confirmatory model was tested using the Goodness of Fit Index. Hair et al. (1998) divided the GOFI (Goodness of Fit Index) criteria into 3 types of criteria, namely absolute fit indices, incremental fit indices and parsimony fit indices. Of the three types of GOFI there are 25 criteria in total, but according to Hair et al. (2010) the SEM-Amos analysis does not require that all criteria be met, 4-5 criteria are sufficient as long as there are criteria that represent the three types of GOFI criteria. In this study, several criteria were taken from each type of GOFI, namely Chi-square, probability, RMSEA, ECVI and GFI representing absolute fit indices, CFI and TLI representing incremental fit indices then PGFI and PNFI representing parsimony fit indices.

Table 2: First GOF Test

\begin{tabular}{lllll}
\hline Fit Index & Goodness of Fit & Criteria & Cut-off value & Result \\
\hline Absolute Fit & Chi-square & Kecil & 285,440 & Not Fit \\
\cline { 2 - 5 } & Probability & $\geq 0.05$ & 0,000 & Not Fit \\
\cline { 2 - 5 } & CMINDF & $<2,00$ & 2,637 & Not Fit \\
\cline { 2 - 4 } & RMSEA & $<0,08$ & 0,081 & Marginal Fit \\
\cline { 2 - 4 } & ECVI & $<2,00$ & 2,785 & Not Fit \\
\cline { 2 - 5 } Incremental Fit & GFI & $\geq 0.90$ & 0,817 & Marginal Fit \\
& CFI & $\geq 0.90$ & 0,894 & Marginal Fit \\
\cline { 2 - 4 } & TLI & $\geq 0.90$ & 0,879 & Marginal Fit \\
\cline { 2 - 4 } & NFI & $\geq 0.90$ & 0,841 & Marginal Fit \\
\hline Parsimony Fit & PGFI & $\geq 0.60$ & 0,657 & Fit \\
\cline { 2 - 4 } & PNFI & & 0,738 & Fit \\
\hline
\end{tabular}

From the results of the goodness of fit test in table 2, it can be seen that there are still 4 criteria that are not fit. Therefore, to increase the GOF value, it is necessary to modify the model that refers to the modification index table by providing a covariance relationship or eliminating indicators that have a high MI (Modification Index) value. In the model modification process, there are several indicators that must be eliminated because they have high MI (Modification Index) values, namely EW2, BI1, MB1 and KK1.

After modifying the results, it shows that the Goodness of Fit value has met all the criteria except for 2 criteria, namely Chisquare and probability (there is no modification index that can be followed to increase GOF), but according to Hair et al. (2010) there are enough representatives of each type of GOF that have a Fit value, in this study it was GFI, ECVI, RMSEA and CMINDF whose fit represents the absolute fit index so it can be tolerated. Schlermelleh-Engel et al. (2003, Vandenberg 2006) stated that chi-square and probability should not be used as the basis for GOF because they are very sensitive to sample size. The result shown in the table 3 .

Table 3: Final GOF Test

\begin{tabular}{lllll}
\hline Fit Index & Goodness of Fit & Criteria & Cut-off value & Result \\
\hline Absolute Fit & Chi-square & Small & 200,56 & Not Fit \\
\cline { 2 - 5 } & Probability & $\geq 0.05$ & 0,00 & Not Fit \\
\cline { 2 - 5 } & CMINDF & $<2,00$ & 1,43 & Fit \\
\cline { 2 - 5 } & RMSEA & $<0,08$ & 0,04 & Fit \\
\cline { 2 - 5 } & ECVI & $<2,00$ & 1,21 & Fit \\
\cline { 2 - 5 } Incremental Fit & GFI & $\geq 0.90$ & 0,92 & Fit \\
& CFI & $\geq 0.90$ & 0,98 & Fit \\
\hline Parsimony Fit & TLI & $\geq 0.90$ & 0,97 & Fit \\
\cline { 2 - 5 } & NFI & $\geq 0.60$ & 0,93 & Fit \\
\cline { 2 - 4 } & PNFI & $\geq 0.60$ & 0,68 & Fit \\
\hline
\end{tabular}

\section{Hypothesis Test}

The next analysis is the full model Structural Equation Model (SEM) analysis to test the hypotheses developed in this study. The results of the regression weight test in this study are as shown in Figure 2 and table 4. 


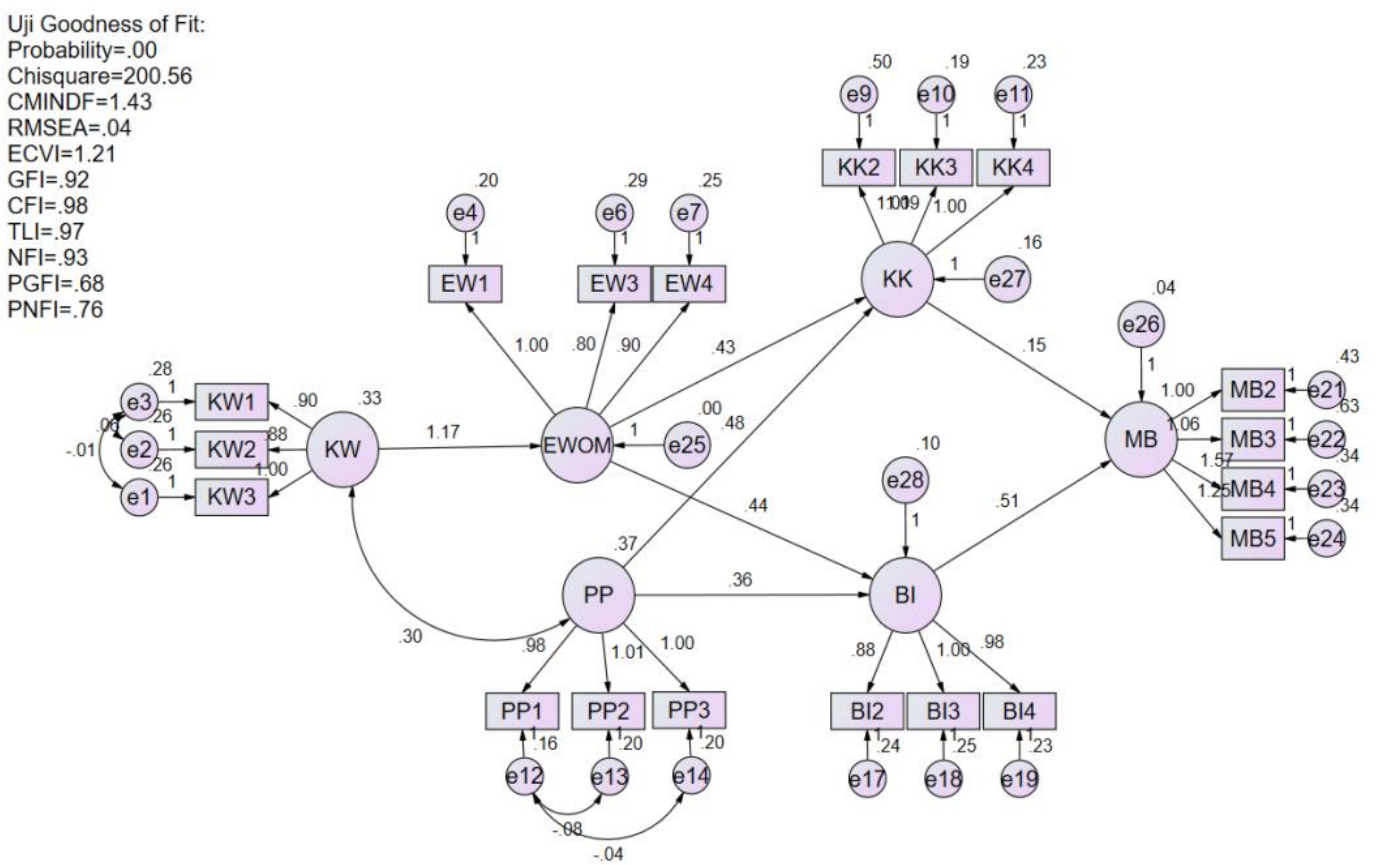

Figure 2: Final Model After Modification

Table 4: Regression Weight

\begin{tabular}{|c|c|c|c|c|c|c|c|}
\hline & & & Estimate & S.E. & C.R. & $\mathrm{P}$ & Keterangan \\
\hline EWOM & $<--$ & KW & 1.168 & .091 & 12.777 & .000 & Positif signifikan \\
\hline KK & $<--$ & EWOM & .427 & .157 & 2.721 & .007 & Positif signifikan \\
\hline $\mathrm{BI}$ & $<--$ & EWOM & .441 & .135 & 3.281 & .001 & Positif signifikan \\
\hline KK & $<--$ & PP & .477 & .174 & 2.736 & .006 & Positif signifikan \\
\hline BI & $<--$ & PP & .355 & .147 & 2.420 & .016 & Positif signifikan \\
\hline MB & $<--$ & KK & .153 & .059 & 2.588 & .010 & Positif signifikan \\
\hline MB & $<---$ & BI & .510 & .089 & 5.764 & .000 & Positif signifikan \\
\hline
\end{tabular}

The results of hypothesis testing can be seen by looking at the Critical Ratio (CR) value and the probability (P) value from the results of data processing. The direction of the relationship between variables can be seen from the estimate value, if the estimate value is positive then the relationship between the variables is positive, whereas if the estimate value is negative, the relationship is negative. Furthermore, if the test results show a CR value above 1.96 and a probability value $(\mathrm{P})$ below $0.05 / 5 \%$, the relationship between exogenous and endogenous variables is significant. In detail, the research hypothesis testing will be discussed in stages according to the proposed hypothesis. The results of the analysis in Table 4 show that:

i. Website quality $(\mathrm{KW})$ has a positive and significant effect on EWOM. These results are evidenced by a positive estimate value of 1.168 , a statistical t value of $>1.96$ which is 12.777 and a probability value of $<0.05$ which is 0.000 . So that $\mathrm{H} 1$ in this study is supported.

ii. EWOM has a positive and significant effect on consumer satisfaction (KK). This result is evidenced by a positive estimate value of 0.427 , a statistical $t$ value of $>1.96$ which is 2.721 and a probability value of $<0.05$ which is 0.007 . So that $\mathrm{H} 2$ in this study is supported.

iii. EWOM has a positive and significant effect on brand image (BI). This result is evidenced by a positive estimate value of 0.441 , the value of $\mathrm{t}$ statistic $>1.96$ which is 3.281 and a probability value of $<0.05$, which is 0.001 . So that $\mathrm{H} 3$ in this study is supported.

iv. The receiver perspective (PP) has a positive and significant effect on consumer satisfaction (KK). These results are evidenced by a positive estimate value of 0.477 , a statistical $t$ value of $>1.96$ which is 2.736 and a probability value of $<$ 0.05 which is 0.006 . So that $\mathrm{H} 4$ in this study is supported.

v. The receiver perspective (PP) has a positive and significant effect on brand image (BI). These results are evidenced by a positive estimate value of 0.355 , a statistical $t$ value of $>1.96$ which is 2.420 and a probability value of $<0.05$ which is 0.016. So that H5 in this study is supported. 
vi. Consumer satisfaction (KK) has a positive and significant effect on purchase intention (MB). These results are evidenced by a positive estimate value of 0.153 , a statistical $t$ value of $>1.96$ which is 2.588 and a probability value of $<0.05$ which is 0.010 . So that $\mathrm{H6}$ in this study is supported.

vii. Brand image (BI) has a positive and significant effect on purchase intention (MB). These results are evidenced by a positive estimate value of 0.510 , a statistical $t$ value of $>1.96$ which is 5.764 and a probability value of $<0.05$, which is 0.000 . So that $\mathrm{H} 7$ in this study is supported.

\section{Discussion}

This study analyzes 6 variables related to marketing on online shopping platforms, namely website quality (KW), EWOM (electronic word of mouth), recipient perspective (PP), consumer satisfaction (KK), brand image (BI) and online purchase intention (MB). From six variables, it was developed based on the theory and previous research into 7 hypotheses which were analyzed in this study. Of the 7 hypotheses analyzed, it was concluded that all the hypotheses in this study were supported.

The first hypothesis in this study is that the quality of the website has a positive and significant effect on EWOM. The results of the analysis in this study support the first hypothesis so that it is proven that the better the quality of the website or online shopping platform application, the positive EWOM will increase. These results are supported by several previous studies by Aslam et al., (2019; Septiari, 2018; Setyaning \& Nugroho, 2020; Yang et al., 2015; Bilal et al., 2020).

Website quality and information quality are the main sources to attract consumers. A quality website is a website that has a fast response to consumers so that it can quickly attract new customers. Website quality relates to user evaluations regarding the fulfillment of their needs. Several previous studies have discussed the importance of website quality and its influence on the creation of E-WOM. Aslam et al. (2019) analyzes the role of website quality on 253 online shopping platform consumers and results that with a good website quality, consumers will give good responses and E-WOM is formed. Likewise with Septiari (2018) who analyzed 200 Atma Jaya Yogyakarta students and found that trust and website quality had an effect on E-WOM and E-WOM had an effect on online purchase intention. E-WOM also mediates the relationship between website quality and online purchase intention. Likewise, the findings by Setyaning \& Nugroho, (2020) which state that website characteristics have an important role in creating E-WOM for 340 e-retailer consumers in Indonesia. Website characteristics consist of several aspects, namely shopping convenience, website design, informativeness, security, communication. All of these aspects have a significant effect on consumer satisfaction and eWOM except shopping convenience and informativeness.

From the results of the first hypothesis analysis, it is expected that online shopping platform managers should pay attention to website quality to improve EWOM. Website quality is the result of user evaluation of a website including ease of use, usefulness, level of attractiveness and easy access (Aslam et al. 2020). To improve the quality of the website, there are several things that need to be considered, namely an attractive website appearance, complete information provided and reviews from consumers or website visitors (Aslam et al. 2020).

The second hypothesis in this study is that EWOM has a positive and significant effect on consumer satisfaction. The results of the analysis in this study indicate that the second hypothesis is supported, so it is evident that the better the increase in EWOM in the online platform, the consumer satisfaction will increase. These results are supported by several previous studies by Setiawan et al., (2014; Tandon et al., 2020; Kuo \& Nakhata, 2019; Aakash \& Gupta, 2020; Aslam et al., 2019).

Consumers see the promotion of E-WOM as something more persuasive and trustworthy. If any brand of a product has negative reviews online on any website on that particular brand it will greatly affect the brand and is a serious problem. Nowadays consumers interact more by word of mouth, they share experiences with a wide audience and communicate with them. Moreover, these brands also have excessive information about their products, making it easier for consumers to check product reviews and details before buying them (Setiawan et al. 2014). When positive reviews are associated with brands, consumers are automatically affected and will be satisfied with certain brands, but when negative reviews are associated with them consumers will be dissatisfied and this will lower their brand quality even if brand quality is high but those specific negative reviews reduce purchase. Here's the reason; any brand faces difficulty responding to negative reviews (Kala \& Chaubey, 2018). From the results of the second hypothesis analysis, it is necessary to underline that EWOM is an important aspect in increasing consumer satisfaction. There are several aspects that make up EWOM and are able to increase consumer satisfaction, namely positive opinions, convincing information, objective comments and trusted sources (Aslam et al. 2020).

The third hypothesis in this study is that EWOM has a positive and significant effect on brand image. The results of the analysis in this study support the third hypothesis, so it is evident that the increasing intensity of EWOM in the online shopping platform will increase the brand image of the platform. These results are supported by several previous studies by Kala \& Chaubey, (2018; Tariq et al., 2017; Farzin \& Fattahi, 2018; Al Halbusi \& Tehseen, 2018; Aslam et al., 2019).

E-WOM has an important role in marketing a product or is an effort to improve the brand. Although there are studies that state that in certain cases, E-WOM is not able to have a significant influence on the brand of a product as research by Syahdiany \& Trinanda (2019) who conducted an analysis on Transmart consumers in Padang and Pasaribu \& Sugiarto which conducted an analysis on smartphone consumers. Oppo in Medan. However, the majority of previous researchers found that E-WOM was able to have a 
significant effect on the company's brand. The E-WOM has several measurements, namely credibility which is the accuracy of the information provided by an e-commerce platform. Then quality is the quality of information submitted by other consumers whether it is trustworthy or not, whether honest or not and the next measurement is quantity, namely the number of reviews given by other users regarding a product. The more reviews given, the more people buy the product (Aslam et al. 2019).

From the results of the third hypothesis analysis, it is necessary to underline that the image can be developed with a positive EWOM intensity. E-WOM is a communication of two parties or one party only in social media about the evaluation of a product (Aslam et al. 2020). The measurements are as follows (Aslam et al. 2020). There are several aspects that make up EWOM and are able to increase consumer satisfaction, namely positive opinions, convincing information, objective comments and trusted sources (Aslam et al. 2020).

The fourth hypothesis in this study is that the receiver perspective has a positive and significant effect on consumer satisfaction. The results of the analysis in this study indicate that the fourth hypothesis is supported, so it is evident that with a good recipient perspective, consumer satisfaction increases. These results are supported by several previous studies by Moore \& Lafreniere, (2020; Heo, 2020; Aslam et al., 2019).

The receiver perspective has an important role in marketing a product or service. Even more so if the marketing is done online. Several previous studies have empirically proven the important role of recipient perspective such as Heo, (2020) who analyzed 425 consumers in Korea and found that E-WOM, recipient perspective and consumer satisfaction. E-WOM affects the characteristics of the sender of information and the characteristics of the recipient of information. The characteristics of the recipient of information, and online communication have a statistically significant effect on the benefits of product risk and consumer satisfaction. Moore $\&$ Lafreniere, (2020) found that WOM (Word of Mouth) has an effect on the receiver perspective and the receiver perspective has an effect on review, helpfulness, satisfaction from consumers

From the results of the analysis in this study, it is hoped that the manager of the online shopping platform will be able to create a good recipient perspective because it can increase consumer satisfaction. Aslam et al. (2020) emphasizes three things in shaping the perspective of the recipient, namely comments as considerations, comments that are able to provide influence and comments to form opinions.

The fifth hypothesis in this study is the perspective of the recipient has a positive and significant effect on brand image. The results of the analysis in this study indicate that the fifth hypothesis is supported, so it is evident that the better the receiver perspective, the better the brand image of the online shopping platform. These results are supported by several previous studies by Le et al., (2018; Kursan et al., 2020; Aslam et al., 2019). Le et al., (2018) who analyzed 509 consumers and found that the receiver's perspective described by the quality of consumer messages related to a product or service can affect the impact of E-WOM in product marketing. The impact of E-WOM in question is consumer satisfaction and brand image. Meanwhile, Kursan et al., (2020) found in an analysis of 1000 consumers in Croatia that the Senders' and Receivers' Perspectives cover several characteristics, namely gender, age, income, education, shopping innovation, shopping convenience, price sensitivity and response to advertising. effect on E-WOM spread and E-WOM seek. Furthermore, WOM spread and WOM seek affect buying intention

The results of the analysis of the fifth hypothesis indicate that the manager of the online buying and selling platform should be able to build a good recipient perspective. The receiver perspective is a response from recipients of information related to a product or service about the information received (Aslam et al. 2019). Aslam et al. (2020) emphasizes three things in shaping the perspective of the recipient, namely comments as considerations, comments that are able to provide influence and comments to form opinions.

The sixth hypothesis in this study is that consumer satisfaction has a positive and significant effect on purchase intention. The results of the analysis in this study indicate that the sixth hypothesis is supported, so it is evident that the better consumer satisfaction, the more consumers buy interest in online shopping platforms. These results are supported by several previous studies by Tandon et al., (2020; Cuong, 2020; Dash et al., 2021; Khatoon et al., 2020; Dhingra et al., 2020). Although there are contradictory findings by Hutchinson (2009; Permana et al. 2020) who found that satisfaction had no significant effect on purchase intention.

Consumers have the characteristic that they always compare the expected expectations of a product with the reality of the product that has been purchased or consumed. Consumers after making a purchase will make a comparison between expectations before making a purchase with the actual situation after making a purchase. Consumer decisions about a purchase are very complex, a professional salesperson must know how to determine a buyer's needs, how to accept new ideas and how psychological stress can affect a purchase (Dash et al. 2021). Khatoon et al., (2020) conducted an analysis on 235 bank employees and customers in Qatar and found that (E)-banking service quality and satisfaction had a significant effect on purchase intention. Furthermore, satisfaction mediates the relationship between E-banking service quality and consumer purchase intention. Likewise with Dhingra et al., (2020) who conducted an analysis on 278 popular website users and found that online service quality and consumer satisfaction had a significant effect on consumer purchase intention.

The results of the sixth hypothesis analysis suggest that online buying and selling platform managers pay attention to consumer satisfaction, so as to increase people's purchase intention. In shaping consumer satisfaction, it is necessary to provide several aspects, namely pleasure by post-purchase consumers because of satisfaction with the product, new experiences that the product can provide, trust and recommendations (Aslam et al. 2020). 
The seventh hypothesis in this study is that brand image has a positive and significant effect on purchase intention. The results of the analysis in this study indicate that the seventh hypothesis is supported, so it is evident that an increase in brand image will have an impact on increasing consumer purchase intention on online buying and selling platforms. These results are supported by several previous studies, namely Farzin \& Fattahi, (2018; Hien et al., 2020; Kala \& Chaubey, 2018)

Several previous studies have analyzed and proven the important role of brand image for a company in its marketing concept. Hien et al., (2020) analyzed 283 consumers of household electrical appliances in Ho Chi Minh and Da Nang cities and found that country of origin had an effect on brand image and brand evaluation. Furthermore, brand image and brand evaluation have an effect on purchase intention. The influence of brand image on purchase intention is also empirically proven by Farzin \& Fattahi, (2018) on students at Azad Islamic University and Al Halbusi \& Tehseen, (2018) on automobile industry consumers in Malaysia. Another finding by Kala \& Chaubey, (2018) found that in a sample of 313 online consumers in India it was found that brand image has an effect on purchase intention and brand image is able to moderate the relationship between E-WOM and purchase intention. Likewise, Tariq et al., (2017) who analyzed 300 consumers in Rawalpindi and Islamabad found that brand image had an effect on purchase intention and brand image was also able to mediate the relationship between E-WOM and brand awareness on purchase intention.

The results of testing the seventh hypothesis indicate that the brand image on an online shopping platform must be considered. Brand image is basically a product's reputation and perceptions created in the minds of customers (Hien et al. 2020). In improving the brand image, several aspects need to be considered, namely building a different image from competitors, building a clean image, building a strong position in the market and increasing brand competitiveness.

\section{Conclusion}

This study provides empirical findings in building purchase intention on online shopping platform consumers. There are two aspects that directly influence the purchase intention of consumers, namely consumer satisfaction and brand image. Companies that manage e-commerce platforms should pay attention to these two aspects because with the increase in consumer satisfaction and brand image, purchase intention in online shopping will increase. On the other hand, this study also analyzes what aspects can increase consumer satisfaction and brand image. The results of the analysis found that an increase in E-WOM and receiver perspectives was able to increase consumer satisfaction and brand image. Another finding in this study also emphasizes the role of website quality on online shopping platforms because good website quality will increase positive E-WOM. From the results of the analysis in this study, the authors recommend several suggestions, namely for online shopping platform managers to pay more attention to and emphasize the quality of the website, EWOM, and recipient perspectives so as to increase consumer satisfaction and brand image. Furthermore, with consumer satisfaction and a good brand image, it is able to increase purchase intention on online shopping platforms. As for further researchers, it is recommended to expand the scope of research and compare or combine other variables in an effort to increase online consumer satisfaction, online shopping platform image and online shopping purchase intention.

Author Contributions: Conceptualization, AIW, AI.; Methodology, AIW, AI.; Data Collection, AIW, AI.; Formal Analysis, AIW, AI.; —Original Draft Preparation, AIW, AI.; Writing — Review And Editing, AIW, AI.; All authors have read and agreed to the published the final version of the manuscript.

Institutional Review Board Statement: Ethical review and approval were waived for this study, due to that the research does not deal with vulnerable groups or sensitive issues.

Data Availability Statement: The data presented in this study are available on request from the corresponding author. The data are not publicly available due to privacy.

Conflicts of Interest: The authors declare no conflict of interest.

\section{References}

Aakash, A., \& Gupta Aggarwal, A., (2020). Assessment of hotel performance and guest satisfaction through eWOM: big data for better insights. International Journal of Hospitality \& Tourism Administration, 1-30. https://doi.org/10.1080/15256480.2020.1746218

Al Halbusi, H., \& Tehseen, S., (2018). The Effect of Electronic Word-Of-Mouth, EWOM; On Brand Im-age and Purchase Intention: A Conceptual Paper. Socio Economic Challenges. 2(3), 83-94. http://essuir.sumdu.edu.ua/handle/123456789/71595

Aslam, W., Farhat, K., \& Arif, I., (2019). Role of electronic word of mouth on purchase intention. International Journal of Business Information Systems, 30(4), 411-426. 10.1504/IJBIS.2019.10020633

Bilal, M., Jianqiu, Z., Akram, U., Tanveer, Y., Sohaib, M., \& Raza, M. A. A., (2020). The Role of Motivational Factors for Determining Attitude Towards eWOM in Social Media Context. International Journal of Enterprise Information Systems, IJEIS), 16(2), 73-91. 10.4018/IJEIS.2020040105

Cuong, D. T., 2020). The Impact of Brand Credibility and Perceived Value on Customer Satisfaction and Purchase Intention at Fashion Market. Journal of Advanced Research in Dynamical and Control Systems,20, 22. 10.5373/JARDCS/V12SP3/20201308

Dash, G., Kiefer, K., \& Paul, J., (2021). Marketing-to-Millennials: Marketing 4.0, customer satisfaction and purchase intention. Journal of Business Research, 122, 608-620. https://doi.org/10.1016/j.jbusres.2020.10.016 
Dhingra, S., Gupta, S., \& Bhatt, R., (2020). A study of relationship among service quality of E-commerce websites, customer satisfaction, and purchase intention. International Journal of E-Business Research, IJEBR), 16(3), 42-59. 10.4018/IJEBR.2020070103

Farzin, M., \& Fattahi, M. (2018). eWOM through social networking sites and impact on purchase intention and brand image in Iran. Journal of Advances in Management Research,15(2), 161-183. https://doi.org/10.1108/JAMR-05-2017-0062

Fishbein, M., \& Ajzen, I. (1975). Belief, Attitude, Intention, and Behavior: An Introduction to Theory and Research. Reading, MA: Addison-Wesley.

Hair, J. F. Jr., Black, W. C., Babin, B. J., \& Anderson, R. E., (2010), Multivariate Data Analysis, 7th Edition, Person Prentice Hall, Essex, UK

Hien, N., Phuong, N., Tran, T., \& Thang, L., (2020). The effect of country-of-origin image on purchase intention: The mediating role of brand image and brand evaluation. Management Science Letters, 10(6), 1205-1212. 10.5267/j.msl.2019.11.038

Heo, Y. W. (2020). The effect of online WOM of menu product consumers on product perception risk and WOM effect. The Journal of Distribution Science, 18(3), 77-85.

Kotler, Philip dan Kevin Lane Keller. (2009). Manajemen Pemasaran. Edisi ke 13. Jakarta: Erlangga

Kursan Milaković, I., Anić, I. D., \& Mihić, M., (2020). Drivers and consequences of word-of-mouth communication from the senders' and receivers' perspectives: the evidence from the Croatian adult population. Economic Research-Ekonomska Istraživanja, 33(1), 1667-1684.

Khatoon, S., Zhengliang, X., \& Hussain, H., (2020). The Mediating Effect of customer satisfaction on the relationship between Electronic banking service quality and customer Purchase intention: Evidence from the Qatar banking sector. SAGE Open, 10(2), 2158244020935887.

Kala, D., \& Chaubey, D. S. (2018). The effect of eWOM communication on brand image and purchase intention towards lifestyle products in India. International Journal of Services, Economics and Management,9(2), 143-157. http://dx.doi.org/10.15722/jds.18.3.202003.77

Kuo, H. C., \& Nakhata, C. (2019). The impact of electronic word-of-mouth on customer satisfaction. Journal of Marketing Theory and Practice, 27(3), 331-348. 10.1504/IJSEM.2018.10017351

Kominfo (kementrian Komunikasi dan Informatika). (2020). Pengguna Media Sosial di Indonesia.

Le, T. D., Dobele, A. R., \& Robinson, L. J. (2018). WOM source characteristics and message quality: the receiver perspective. Marketing Intelligence \& Planning. 36(4), 410-424. https://doi.org/10.1108/MIP-10-2017-0249

Moore, S. G., \& Lafreniere, K. C. (2020). How online word-of-mouth impacts receivers. Consumer Psychology Review, 3(1), 34-59. https://doi.org/10.1002/arcp.1055

Schermelleh-Engel, K., Moosbrugger, H., \& Müller, H. (2003). Evaluating the fit of structural equation models: Tests of significance and descriptive goodness-of-fit measures. Methods of psychological research online, 8(2), 23-74. 10.1504/IJSEM.2018.096077

Setiawan, P. Y., Troena, E. A., \& Armanu, N. (2014). The effect of e-WOM on destination image, satisfaction and loyalty. International Journal of Business and Management Invention, 3(1), 22-29. https://erepo.unud.ac.id/id/eprint/5023

Septiari, E. D., 2018). The Effect of eWOM as Mediation of Website Quality and Trust. Kinerja, 22(2), $142-155$. https://doi.org/10.24002/kinerja.v22i2.1810

Setyaning, A. N. A., \& Nugroho, S. S. (2020). The influence of website characteristics on customer satisfaction and E-WOM in Indonesia. Jurnal Siasat Bisnis, 24(2), 148-167. 10.20885/jsb.vol24.iss2.art5

Tandon, A., Aakash, A., \& Aggarwal, A. G. (2020). Impact of EWOM, website quality, and product satisfaction on customer satisfaction and repurchase intention: moderating role of shipping and handling. International Journal of System Assurance Engineering and Management, 1-8. 10.1007/s13198-020-00954-3

Tariq, M., Abbas, T., Abrar, M., \& Iqbal, A. (2017). EWOM and brand awareness impact on consumer purchase intention: mediating role of brand image. Pakistan Administrative Review, 1(1), 84-102. https://nbn-resolving.org/urn:nbn:de:0168-ssoar-518768

Vandenberg, R. J. (2006), Statistical and Methodological Myths and Urban Legends, Organizational Research Methods, 9(2). 194201. https://doi.org/10.1177/1094428105285506

Yang, K., Li, X., Kim, H., \& Kim, Y. H. (2015). Social shopping website quality attributes increasing consumer participation, positive eWOM, and co-shopping: The reciprocating role of participation. Journal of Retailing and Consumer Services, 24, 1-9. https://doi.org/10.1016/j.jretconser.2015.01.008

Publisher's Note: SSBFNET stays neutral with regard to jurisdictional claims in published maps and institutional affiliations.

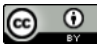

(C) 2022 by the authors. Licensee SSBFNET, Istanbul, Turkey. This article is an open access article distributed under the terms and conditions of the Creative Commons Attribution (CC BY) license (http://creativecommons.org/licenses/by/4.0/).

International Journal of Research in Business and Social Science (2147-4478) by SSBFNET is licensed under a Creative Commons Attribution 4.0 International License. 